Ann. Génét. Sél. anim., I980, 12 (3), 29r-293.

\title{
Chromosome constitution of a hybrid between East African Buffalo (Syncerus caffer caffer) and Dwarf Forest Buffalo (Syncerus caffer nanus)
}

\author{
E. P. CRIBIU and C. P. POPESCU \\ with the technical collaboration of Jeanitie BOSCHER \\ Laboratoive de Cytogénétique UNCEIA-I.N.R.A., \\ Centre national de Recherches zootechniques, I.N.R.A., \\ F 78350 Jouy-en-Josas (France)
}

\begin{abstract}
Summary
The chromosome constitution of a male hybrid of first backcross between a female Fi East African $\times$ Dwarf African Buffalo (Syncerus caffer caffer $\times$ Syncerus caffer nanus) and a male Dwarf Forest Buffalo (Syncerus caffer nanus) had a chromosome number of $53: 2$ I acrocentric pairs, 2 unpaired acrocentrics, 3 meta-submetacentric pairs, I unpaired submetacentric and I acrocentric XY sex chromosome pair. The R-banding pattern shows that the chromosomic difference between the subspecies caffer $(2 n=54)$ and nanus $(2 n=52)$ is due to a centric fusion between two acrocentric pairs.
\end{abstract}

Karyotypes of the two subspecies of African Buffalo, East African (Syncerus caffer caffer) and Dwarf Forest (Syncerus caffer nanus), have already been described (WURSTER and BENIRSCHKE, I967; ULBRICH and FISCHER, I967 and HECK et al., I968).

The Dwarf Forest type had 54 chromosomes, among which 3 autosomal pairs were meta-submetacentric and 23 were acrocentric, with the $X$ and $Y$ being acrocentric. When compared to the karyotype of Dwarf Forest Buffalo, the East African Buffalo demonstrated 52 chromosomes with one submetacentric pair instead of two acrocentric pairs.

The present report describes the chromosome constitution of a male hybrid of first backcross between a female FI and a male Dwarf Forest Buffalo. The animal (No I6569) born in I969 and kept in Parc Zoologique de Paris, was slaugh- 

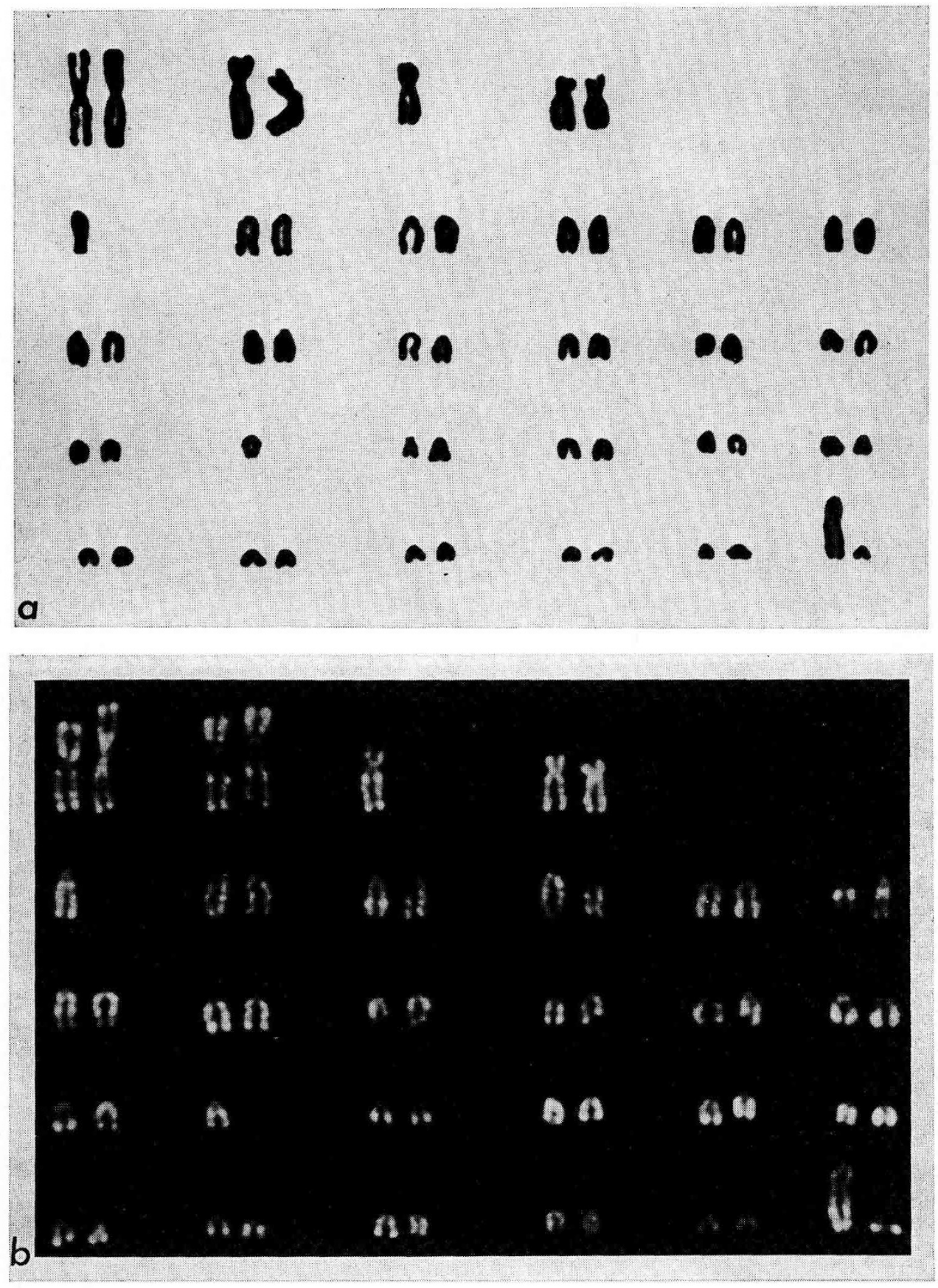

FIG. I. - Chromosome constitution of the male hybrid (nanus $\times$ (nanus $\times$ caffer))

a) Conventional staining karyotype.

b) R-banding karyotype.

Caryotype de l'hybride mâle (nanus $\times$ (nanus $\times$ caffer))

a) Caryotype en coloration classique.

b) Caryotype avec marquage $\mathbf{R}$. 
tered in April rg8o. It has recently been included in a study for heredity of coat colour variation by LAUVERGNE and RENVOISÉ (I980).

For chromosome observations, a blood sample was obtained from the jugular vein and cultivated according to the method of DE GROUCHY et al. (I964); Rbanding was achieved by the technique of DuTrILLAUx et al. (I973).

The number of chromosomes in the hybrid is 53 , among which a submetacentric and two acrocentrics are not paired. All other chromosome pairs are homomorphic except the XY sex chromosome pair. Two acrocentric pairs exhibit large small arms (fig. I, $a$ ).

By using $\mathrm{R}$-banding technique, all chromosome pairs could be identified. $\mathrm{R}$-banding pattern of $p$ and $q$ arms of the unpaired submetacentric chromosome is characteristic of the two unpaired acrocentric autosomes (fig. I, $b$ ).

It is obvious that the unpaired submetacentric chromosome originated from the East African type whereas the two unpaired acrocentric autosomes were derived from the Dwarf Forest type.

In regard to the karyotype evolution of the two subspecies of African Buffalo, it could be suggested that the Dwarf type with $2 n=54$ occured first and during evolution, the East African type should have developed by Robertsonian fusion of two acrocentric pairs.

Received for publication in november 1980.

\section{Résumé}

\section{Le caryotype d'un hybride entre le Buffe Africain (Syncerus caffer caffer) et le Buffle nain (Syncerus caffer nanus)}

Le caryotype d'un mâle, produit de croisement de retour d'une femelle hybride Fi Buffle Africain $\times$ Buffle nain (Syncerus caffer caffer $\times$ Syncerus caffer nanus) et d'un Buffle nain mâle (Syncerus caffer nanus) est composé de 53 chromosomes : 2 I paires acrocentriques, 2 chromosomes acrocentriques non appariés, 3 paires méta-submétacentriques, $x$ chromosome submétacentrique et 2 chromosomes sexuels $\mathrm{X}$ et $\mathrm{Y}$ acrocentriques. Le marquage $\mathrm{R}$ a montré que la différence de caryotype de ces deux sous-espèce est due à une fusion centrique entre đeux paires de chromosomes acrocentriques.

\section{References}

De Grouchy J., Roubin M., Passage E., I964. Microtechnique pour l'étude des chromosomes humains à partir d'une culture de leucocytes sanguins. Ann. Génét., 7, 45.

Dutrilifaux B., LAURENT M., CoUTURIER J., LEJEUNE J., I973. Coloration pout l'acridinle orange de chromosome préalablement traités par le 5 bromodeoxyuridine (B.U.D.R.). C. R. Acad. Sci. (Paris), 276, 3179-3I8I.

HeCK H. D., WuRSTER D. H., BenIRSchke K., r968. Chromosome study of numbers of the subfamilies Caprinae and Bovidae: the muskox, ibec, aoudad, Congo buffalo and Gaur. $Z$. Saügetierk, 33, I 72-I79.

IAUVERGNE J. J., Renvorsé C., I980. Hérédité des variations de couleur du pelage du Buffle africain (Syncerus caffer). Ann. Génét. Sél. Anim., 12, I-7.

ULBRICH F., FISCHER M., 1967. The chromosomes of the Asiatic buffalo (Bubalus bubalis) and the Africant buffalo (Syncerus caffer). Z. Tierz. Züchtbiol., 83, 219-223.

WURSTER D. H., BENIRSCHKE K., 1967. The chromosomes of twenty-three species of Cervoidae and Bovidae. Mammalian Chomosomes Newsletter, 8, 226-229. 